\title{
Evaluation of Quality Parameters for Cord Blood Donations
}

\author{
Ursula Salge-Bartels ${ }^{\mathrm{a}} \quad$ Helga Marie Huber $^{\mathrm{a}} \quad$ Kornelia Kleiner $^{\mathrm{a}}$ Peter Volkers ${ }^{\mathrm{b}}$ Rainer Seitz \\ Margarethe Heiden ${ }^{a}$ \\ a Division of Hematology / Transfusion Medicine, \\ ${ }^{b}$ Division of EU-Cooperation/Microbiology, Paul Ehrlich Institute, Langen, Germany
}

\section{Key Words}

CD34/CD45+ cells - Clonogenic potential · Cord blood . Hematopoiesis · Stem cells · Viability

\section{Summary}

Background: Umbilical cord blood (CB) is widely used for hematopoietic stem cell transplantation and holds promise for the development of innovative medicinal products. In order to find out whether the conditions for collection and storage before processing might have an impact on the quality of CB preparations, viability and the clonogenic potential were assessed. Methods: CB was collected under field conditions. Flow cytometry was used to determine leukocytes, CD34/CD45+ cells, viability, and nucleated red blood cells (NRBC). Clonogenic activity was determined using isolated mononuclear cells (MNC). Results: Neither plasma citrate concentrations nor storage temperature (within $24 \mathrm{~h}$ ) affected cell viability or colony formation. After storage for $49-80 \mathrm{~h}$, leukocyte viability declined by about $16 \%$ compared to CB stored up to $24 \mathrm{~h}$. In contrast, the clonogenic activity and CD34/CD45+ cell content were not affected. A higher gestational age was associated with a lower yield of clonogenic activity compared to midterm deliveries. NRBC varied widely (median $7.3 \%$; range $0.63-17.3 \%$ ) without relation to gestational age or colony formation. There was a close correlation between the percentage of viable CD34/CD45+ cells and colony formation ( $r=0.77$ for CFU-GM; $r=0.75$ for CFU-C). Conclusions: The content of viable CD34/CD45+ cells represents the clonogenic activity of $\mathrm{CB}$ preparations. Therefore, determination of viable CD34/CD45+ cells should be generally performed as a routine quality control assay.

\section{Schlüsselwörter}

CD34/CD45+ Zellen · Klonogenes Potential · Nabelschnur-/ Plazentarestblut · Hämatopoese · Stammzellen · Vitalität

\section{Zusammenfassung}

Hintergrund: Nabelschnurblut (cord blood; CB) gewinnt zunehmend Bedeutung für die Transplantation hämatopoetischer Stammzellen und bietet darüber hinaus ein vielversprechendes Potential für die Entwicklung innovativer Arzneimittel. Um zu beurteilen, in welcher Weise die Bedingungen der CB-Entnahme und -Lagerung vor der Aufarbeitung die Qualität der Präparate beeinflussen könnte, wurden Untersuchungen zur Vitalität und zur klonogenen Aktivität der Zellen durchgeführt. Methoden: CB-Spenden wurden unter Routinebedingungen entnommen. Die Vitalität, die Zahl der Leukozyten und der CD34/CD45+ Zellen sowie der Gehalt an Erythroblasten wurden durchflusszytometrisch bestimmt. Die Messung des klonogenen Potentials erfolgte mit angereicherten mononukleären Zellen (MNC). Ergebnisse: Weder die Zitratkonzentration noch die Lagertemperatur ( $\leq 24 \mathrm{~h}$ ) beeinflussten die Vitalität und die Koloniebildung der CB-Zellen. Längere Lagerung (4980 h) führte zu einem Verlust der Leukozytenvitalität um etwa $16 \%$ verglichen mit frischem CB $(\leq 24 \mathrm{~h})$. Die koloniebildende Aktivität und der Gehalt an vitalen CD34/CD45+ Zellen blieben dagegen unbeeinflusst. Bei höherem Gestationsalter war das klonogene Zellwachstum vermindert. Der Gehalt an Erythroblasten variierte stark (Median 7.3\%, Bereich 0.63-17.3\%), wies jedoch keine Korrelationen zum Gestationsalter oder zur Koloniebildung auf. Eine enge Korrelation bestand dagegen zwischen dem Gehalt an vitalen CD34/CD45+ Zellen und dem Potential der Koloniebildung ( $r=0,77$ für CFU-GM, $r=0,75$ für CFU-C). Schlussfolgerung: Der Gehalt an vitalen CD34/CD45+ Zellen ist ein Maß für die klonogene Aktivität von CB-Präparaten und sollte daher routinemäßig zur Beschreibung der Produkteigenschaften bestimmt werden.

\section{KARGER

\section{(c) 2009 S. Karger GmbH, Freiburg}




\section{Introduction}

The use of cord blood (CB) as a source of hematopoietic stem cells for the reconstitution of bone marrow after chemotherapy has generated new perspectives in the treatment of hematological diseases and for cellular therapy [1]. CB can be stored frozen for a long period and may be infused to matched patients after minor processing in a process alluded to as cord blood transplantation, in order to restore hematopoiesis, e.g. after high-intensity chemo-/radiotherapy [2,3]. Moreover, CB may evolve into a valuable source of immature cells that may be engineered and manipulated to obtain advanced cell therapy products, e.g. for tissue repair [4] or gene therapy [5]. For all medical applications, it is crucial that the processed cells retain their viability and functional integrity without acquiring any damage or undesired alterations. Thus, in any case where $\mathrm{CB}$ is directly used as a medicinal product or as starting material for advanced products, special requirements have to be implemented in order to ensure high-quality products.

In practice, $\mathrm{CB}$ preparations are usually collected in maternity wards under quite variable conditions and circumstances. Assessment of bacterial contamination and screening for transmittable viral infections of the mothers is of crucial importance [6] and is the major focus of existing guidelines and recommendations. However, it may also be of clinical importance that collected CB preparations are very heterogeneous, due to characteristics of the mothers and circumstances of delivery [7]. Also, a potential impact of different processing methods on cellular composition and function of $\mathrm{CB}$ has to be considered [8]. Deficiencies in quality have been found in a multicenter study in a rather high portion of CB samples [9].

The authors of the present study work in the Paul Ehrlich Institute, the German regulatory authority for licensing of biologicals including hematopoietic stem cells from CB. Until now, the impact of procurement and storage conditions on $\mathrm{CB}$ stem cell quality prior to cryopreservation has not been sufficiently studied. We therefore analyzed CB collected under routine conditions in a nearby hospital and evaluated donation-specific variables such as gestational age, volume, and citrate concentration as well as different storage times and temperatures between $\mathrm{CB}$ withdrawal and cryopreservation.

\section{Material and Methods}

\section{Blood Collection}

This study was initiated after approval of the competent ethics commission (Ethik-Kommission bei der Landesärztekammer Hessen). With the informed consent of the mothers, umbilical CB donations were collected from normal term deliveries in the Asklepios-Klinik, Langen, Germany. A medical questionnaire was used to ask for information on smoking, drug and alcohol consumption, diseases and medications, birth weight, gender, gestational age, Apgar score, and complications during labor. CB was collected into blood bags from Macopharma (Langen, Germany) with $21 \mathrm{ml}$ citrate-phosphate-dextrose (CPD) solution in the primary bag and
$8 \mathrm{ml} \mathrm{CPD}$ in the satellite bag. Prior to analysis, donations were stored in a random manner, either without cooling at ambient temperature (room temperature, $\left.18-26{ }^{\circ} \mathrm{C}\right)$ or refrigerated at $8{ }^{\circ} \mathrm{C}\left(4\right.$ to $\left.-12{ }^{\circ} \mathrm{C}\right)$. According to their different storage periods and conditions, four groups were defined: group A (0-24 h room temperature); group B $\left(0-24 \mathrm{~h} 8^{\circ} \mathrm{C}\right)$; group $\mathrm{C}\left(25-48 \mathrm{~h} 8^{\circ} \mathrm{C}\right)$; and group D $\left(49-80 \mathrm{~h} 8^{\circ} \mathrm{C}\right)$.

\section{Blood Processing}

After inspection of the blood bags for integrity and signs of clotting, blood was transferred into sterile conical $50 \mathrm{ml}$ tubes, and the total volume including the anticoagulant was recorded. Whole CB was used for the microscopic leukocyte count, the preparation of blood smears, and the flow cytometric assay of CD45+ and CD34/CD45+ cells as well as of viability, as described below.

For growth and differentiation assays, mononuclear cells (MNC) were isolated by density gradient centrifugation according to standard procedures. Briefly, following the supplier's instructions, Leucosep ${ }^{\circledR}$ tubes (Greiner Bio-One, Frickenhausen, Germany) were filled with $15 \mathrm{ml}$ Histopaque-1077 ${ }^{\mathrm{TM}}(\mathrm{d}=1.077 \mathrm{~g} / \mathrm{ml}$, Sigma-Aldrich, Taufkirchen, Germany) in the lower compartment and overlaid with a $15 \mathrm{ml}$ aliquot of the CB. After centrifugation (15 min, $800 \times g$, room temperature), MNC were collected, washed twice with phosphate-buffered saline (PBS), and resuspended in Iscove's Modified Dulbecco's Medium (IMDM) (Biochrom, Berlin, Germany) supplemented with 2\% fetal bovine serum (FBS) (Cell Systems, St Katharinen, Germany). Isolated MNC were counted manually and assayed by flow cytometry for absolute numbers of CD45+ and CD34/ CD45+ cells as well as viability. Microscopic manual leukocyte counts in MNC and whole blood were performed in a Neubauer hemocytometer after dilution with Türk's solution.

\section{Flow Cytometry}

Flow cytometry was performed with an EPICS-XL cytometer (Beckman Coulter, Krefeld, Germany). The stemKit ${ }^{\mathrm{TM}}$ (Beckman Coulter) was used for the enumeration of CD45+ and CD34/CD45+ cells. Data analysis was performed with the stemOne ${ }^{\mathrm{TM}}$ System software (Beckman Coulter). The automated gating relies on the ISHAGE protocol [10] with consecutive gating steps counting $\mathrm{CD} 34^{\text {bright }} \mathrm{CD} 45^{\mathrm{dim}}$ cells as stipulated by the European Guidelines [11]. This single platform procedure uses Stem-Count Fluorospheres $^{\mathrm{TM}}$ (Beckman Coulter) at a known concentration to calculate cell concentrations and absolute cell numbers. Viability was assessed by flow cytometry with 7-aminoactinomycin D (7-AAD) staining of dead cells, which was included in the stemKit.

The relative frequency of nucleated red blood cells (NRBC) was determined in the isolated MNC fraction after staining with fluorescein isothiocyanate(FITC)-conjugated CD71 and phycoerythrin(PE)-conjugated glycophorin A (glyA) antibodies (Beckman Coulter). The amount of CD71+/glyA+ cells was expressed as the percentage of all MNC [12].

\section{Colony-Forming Units}

Isolated MNC were used for hematopoietic stem and progenitor cell activity determination in $1 \%$ methylcellulose containing semisolid growth medium. To this end, 2.5 and $1.25 \times 10^{4}$ cells $/ \mathrm{ml}$ were suspended in Metho Cult ${ }^{\mathrm{TM}} \mathrm{H} 4330$ (Cell Systems), which contained $30 \% \mathrm{FBS}$ and $3 \mathrm{U} / \mathrm{ml}$ recombinant human (rh) erythropoietin (EPO), and was supplemented with $10 \mathrm{ng} / \mathrm{ml} \mathrm{rh}$ IL-3, $10 \mathrm{ng} / \mathrm{ml} \mathrm{rh}$ granulocyte macrophage-stimulating factor (GM-CSF), and $50 \mathrm{ng} / \mathrm{ml} \mathrm{rh}$ stem cell factor (SCF) (all Cell Systems). 1 $\mathrm{ml}$ samples were seeded in duplicate in $3.5 \mathrm{~mm}$ plates (NUNC, Wiesbaden, Germany), incubated at $37{ }^{\circ} \mathrm{C}$ at $5 \% \mathrm{CO}_{2}$ and $94 \%$ humidity, and examined microscopically after 14 and 21 days. Scores from day 21 were used for analysis. Colonies were differentiated by phenotype according to: erythroid colony-forming units (CFU-E), granulocyte CFU (CFU-G), colony-forming units macrophage (CFU-M), mixed colonies with granulocytes and macrophages (CFU-GM), and mixed colonies with erythroid cells, granulocytes, macrophages, and megakaryocytes (CFU-GEMM). Colonies were counted under an inverted microscope with 50-fold magni- 
Table 1. Descriptive data of analyzed $\mathrm{CB}$ donations $\mathrm{s}^{\mathrm{a}}$

\begin{tabular}{lll}
\hline & Median & Range \\
\hline Gestational age, weeks $(\mathrm{n}=80)$ & 40 & $37-42$ \\
Birth weight, $\mathrm{g}(\mathrm{n}=79)$ & 3,460 & $2,470-4,670$ \\
Volume including anticoagulant, $\mathrm{ml}(\mathrm{n}=82)$ & 60 & $34-153$ \\
Citrate concentration, $\mathrm{mol} / \mathrm{l}(\mathrm{n}=40)$ & 70 & $14-114$ \\
Time before processing, $\mathrm{h}(\mathrm{n}=82)$ & 22 & $1-80$ \\
Leukocytes $\times 10^{8} /$ donation $(\mathrm{n}=82)^{*}$ & 4.52 & $1.15-10.5$ \\
Viability, \% $(\mathrm{n}=82)^{*}$ & 96.9 & $65.0-99.5$ \\
$\mathrm{CD} 34+$ cells, \% $(\mathrm{n}=82)^{*}$ & 0.23 & $0.04-0.90$ \\
$\mathrm{CD} 34 / \mathrm{CD} 45+$ cells $\times 10^{5} /$ donation $(\mathrm{n}=82)^{*}$ & 9.25 & $1.3-55.8$ \\
\hline
\end{tabular}

${ }^{\mathrm{a}} 1 / 41$ donations analyzed was tested positive for microbial growth.

*Whole CB by flow cytometry single platform assay before processing.

fication according to standard criteria with lower colony cell numbers of 100 for CFU-E and 40 for CFU-M, CFU-G, and CFU-GM, respectively.

Megakaryocyte differentiation was measured with MNC seeded in MegaCult ${ }^{\mathrm{TM}} \mathrm{C}$ (Cell Systems) containing $1.1 \mathrm{mg} / \mathrm{ml}$ bovine collagen, 50 $\mathrm{ng} / \mathrm{ml}$ rh thrombopoietin (TPO), $10 \mathrm{ng} / \mathrm{ml} \mathrm{rh}$ IL-6, and $10 \mathrm{ng} / \mathrm{ml} \mathrm{rh}$ IL-3 according to the supplier's directions. The experiments were performed with cell concentrations of $2.5 \times 10^{4} / \mathrm{ml}$. Four aliquots of $0.5 \mathrm{ml}$ were dispensed in 4-well plates (NUNC). Following 21 days of incubation (at 37 ${ }^{\circ} \mathrm{C}, 5 \% \mathrm{CO}_{2}, 95 \%$ humidity), collagen gels were placed on slides, covered with a nylon mesh and filter paper, and then air-dried. Specimens were fixed in acetone/methanol (1:1), and megakaryocytes and platelets were identified after immunocytochemical staining with anti-CD61 monoclonal antoibodies (moAb) (Beckman-Coulter) and the APAAP-KIT ${ }^{\mathrm{TM}}$ (DAKO, Hamburg, Germany). Nuclear counterstaining was performed with Gill's hematoxylin. Total CFU megakaryocyte (CFU-Meg) counts evaluated colonies with more than 3 megakaryocytes without differentiation according to larger colony size. The mean number of colonies of two wells was used to calculate colony numbers per $10^{5} \mathrm{MNC}$ plated.

Colony numbers per $10^{3} \mathrm{CD} 34 / \mathrm{CD} 45+$ cells were calculated from colony scores per $10^{5} \mathrm{MNC}$ and the percentage of CD34/CD45+ cells in the MNC fraction. The different myeloid colony types were summed up as CFU-myeloid to compare with CFU-E. CFU-C represents total colony counts.

\section{Citrate Determination}

Citrate concentration was determined in plasma samples by the use of a colorimetric assay (citric acid assay, UV-method; R-Biopharm, Darmstadt, Germany) according to the supplier's instructions.

\section{Sterility Testing}

For sterility testing, $2 \mathrm{ml}$ of whole $\mathrm{CB}$ were injected into test flasks for aerobic and anaerobic incubation and were evaluated with the BacTalert ${ }^{\mathrm{TM}}$ system (BioMérieux, Nürtingen, Germany) for at least 5-7 days.

\section{Data Collection and Statistical Analysis}

For this study, all evaluable $\mathrm{CB}$ units were used, irrespective of their compliance with the requirements for donation volume and nucleated cell count in the current guideline specifications [13].

Statistical characteristics such as median and range were used to describe the data. Correlations between quantitative data were described by means of Pearson's correlation coefficient. Lin's concordance correlation coefficient [14] (Lin's CCC, including its 95\% confidence interval) was applied to assess agreement between two methods to determine the cell numbers in MNC preparations. A Kruskall-Wallis test was applied in order to assess the influence of gestational age or storage condition

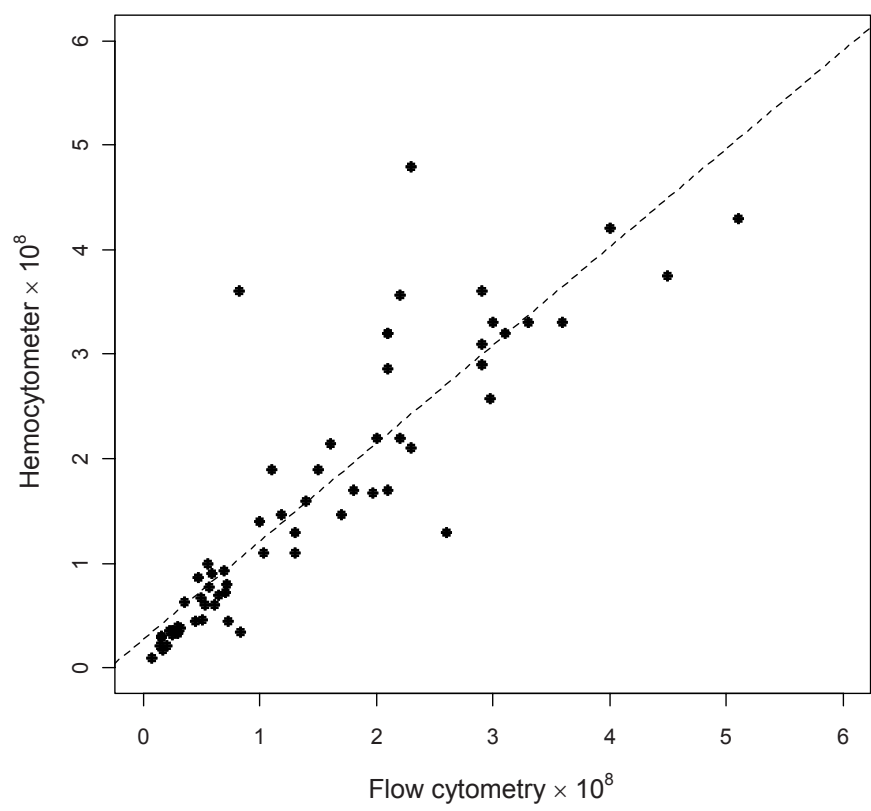

Fig. 1. Determination of leukocyte numbers in $\mathrm{MNC}$ preparations performed by manual counting in a hemocytometer after red blood cell lysis with Türk's solution versus flow cytometric single platform assay with the stemKit. The correlation between the methods is Lin's CCC 0.87 (95\% CI 0.87-0.92).

on various parameters. p-values $<0.05$ were considered statistically significant. If a difference between any groups was found, pair-wise comparisons were performed by means of a Wilcoxon test applying the Holm procedure [15] in order to control the family-wise type I error. Due to a lack of pre-specified hypotheses, all analyses have to be interpreted exploratively.

\section{Results}

A total of $82 \mathrm{CB}$ donations were included in this study. All donations were analyzed irrespective of their volume in order to test the influence of high citrate concentrations and low $\mathrm{pH}$ values. Descriptive data are compiled in table 1. Data were analyzed and outliers checked for possible association with exogenous factors from collection and handling or from behavioral and health conditions. Annotations for all 82 donations were as follows: signs of clotting in the blood bag (3), smoking during pregnancy (7), hypoxia/mild acidosis during delivery (4), gestational diabetes (2), and allergic diathesis (4). They did not coincide with noticeably deviating values for those parameters studied.

Sterility testing was performed on a subset of the samples before further processing showing only one positive sample out of 41 tested. This corresponds to a frequency of $2.4 \%$, which is in the same order of magnitude as a previously reported value of $6.4 \%$ [16]. No signs of contamination were observed in non-tested donations when cells were cultured in the colony assays. 


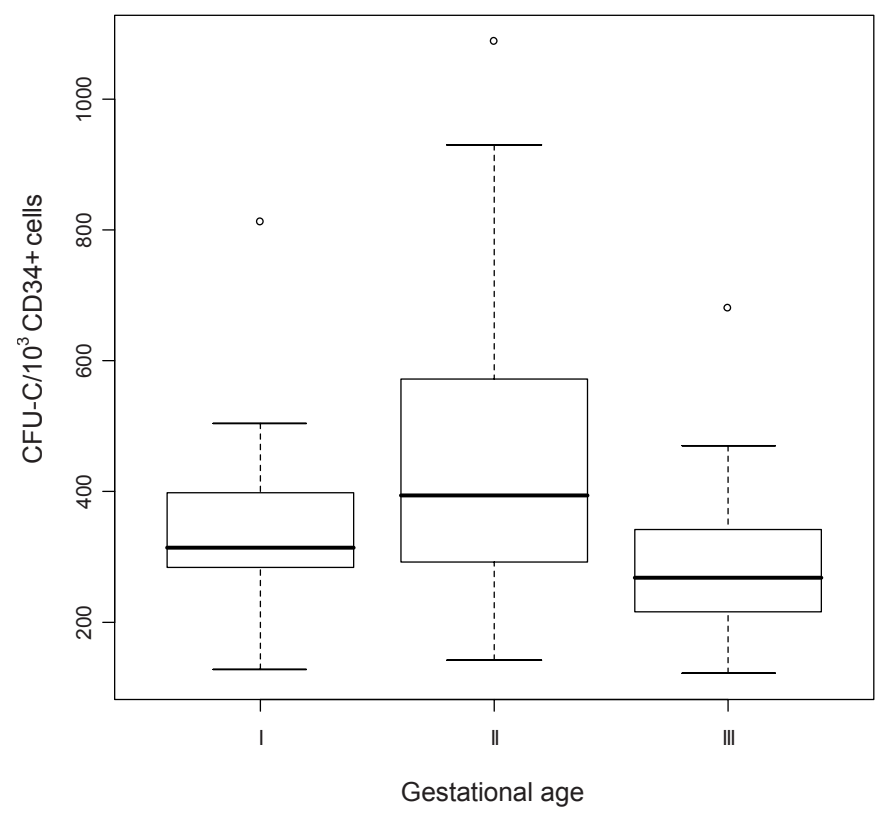

Fig. 2. CFU activity (CFU-C / $10^{3} \mathrm{CD} 34 / \mathrm{CD} 45+$ cells) in relation to the gestational age of $\mathrm{CB}$ donations: group I: 37 th week to 38 th week +6 days, $\mathrm{n}=11$; group II: 39 th week to 40 th week +3 days, $\mathrm{n}=45$; group III: 40th week +4 days to 42 nd week, $n=25$. A significant difference was found between group II and group III $(\mathrm{p}=0.01)$. Amongst others the box plots provide the 1st, 2nd (median) and 3rd quartile of the data.

The manual microscopic cell count of MNC after red cell lysis in Türk's solution was used to adjust the cell concentrations for all cell-based assays. Comparing the cell numbers of MNC determined by microscopic counting with leukocyte numbers obtained by flow cytometry, we found a good agreement (Lin's CCC 0.87, 95\% CI 0.87-0.92; fig. 1). The manual counts showed only slightly higher values, probably due to inclusion of dead cells and erythroblasts.

\section{Citrate Concentrations}

$\mathrm{CB}$ donations contained variable concentrations of anticoagulant due to the wide range of collected blood volume (table 1). In order to assess possible undesirable effects of high citrate concentrations and concurrent acidic $\mathrm{pH}$ values in plasma on hematopoietic cells, we determined the actual plasma citrate concentrations in 40 donations over a specific period. A broad range of citrate concentrations from 14-114 mmol/1 was measured, but no correlation with leukocyte viability, CD34/ CD45+ cell content, or CFU activity was found.

\section{Gestational Age}

Donations from regular deliveries were assigned to three groups according to gestational age: group I: 37 th to 38 th week +6 days, $n=11$; group II: 39 th to 40 th week +3 days, $n$ $=45$; and group III: 40th week +4 days to 42 nd week, $n=25$. Different storage conditions were evenly distributed between groups and were therefore without impact. The only parameter associated with gestational age was the CFU activity per

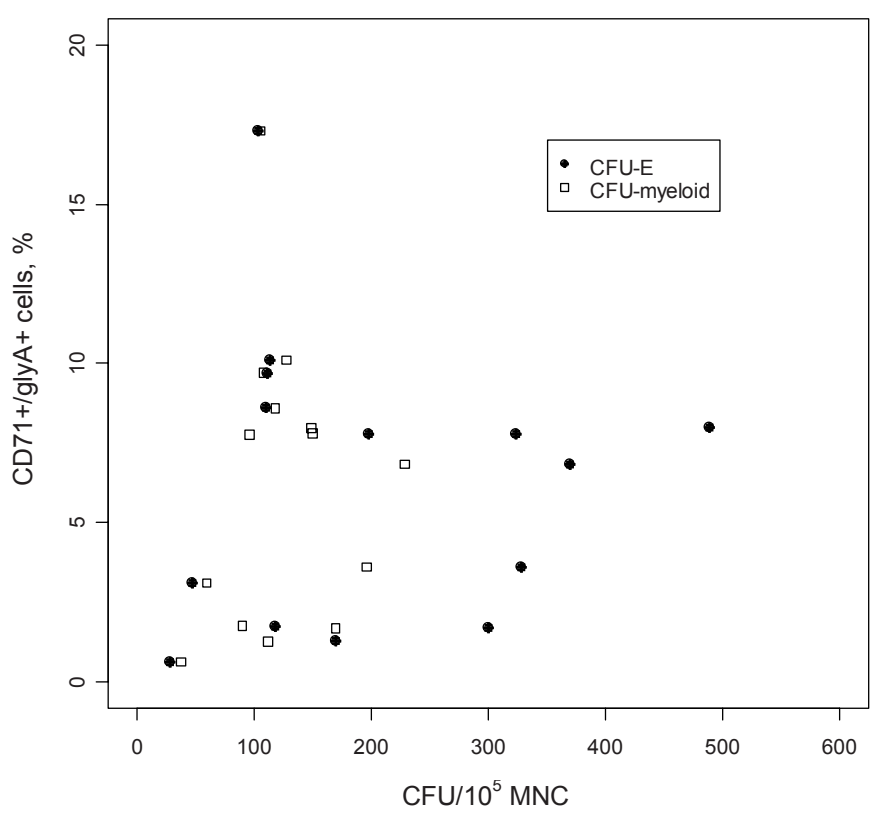

Fig. 3. Relation of NRBC (CD71+/glyA+ cells) frequency in isolated MNC $(\mathrm{n}=14)$ to CFU-E and CFU-myeloid scores (CFU-E / $10^{5} \mathrm{MNC}$, CFU-myeloid / $10^{5} \mathrm{MNC}$ ).

$10^{3} \mathrm{CD} 34 / \mathrm{CD} 45+$ cells, which was significantly higher in group II when compared to group III ( $p=0.01)$ (fig. 2).

\section{Nucleated Red Blood Cells}

As NRBC constitute a variable part of the CB MNC fraction, we determined their frequency in a subset of $14 \mathrm{MNC}$ preparations which were employed for CFU assays. NRBC, staining positive for both CD71 and glyA, were analyzed for a possible influence on colony formation. Median percentage of NRBC was $7.3 \%$ (range $0.63-17.3 \%$ ). No correlation of NRBC values with the CFU-E and CFU-myeloid scores was seen (fig. 3 ), while also in this subset CFU-myeloid scores showed a clear correlation with the frequency of CD34/CD45+ cells (not shown). Furthermore, NRBC content was not correlated with CD34/CD45+ content or with gestational age.

\section{Influence of Storage Conditions}

The impact of storage temperature on $\mathrm{CB}$ quality was assessed comparing room temperature (group A) versus cooling at $8{ }^{\circ} \mathrm{C}$ (group B) for donations stored up to $24 \mathrm{~h}$. No significant differences between the qualities at both temperatures were found within the first $24 \mathrm{~h}$ for leukocyte viability (fig. 4a), content of CD34/CD45+ cells (fig. 4b), and CFU-myeloid scores (fig. 4c).

The influence of storage time was evaluated for refrigerated donations, comparing group B stored up to $24 \mathrm{~h}$, group $\mathrm{C}$ with storage times between 25 and $48 \mathrm{~h}$, and group D with storage times between 49 and $80 \mathrm{~h}$. While there was a high variability in all groups, a loss of leukocyte viability (fig. 4a) was observed with increasing storage time. In contrast, the CD34/ 

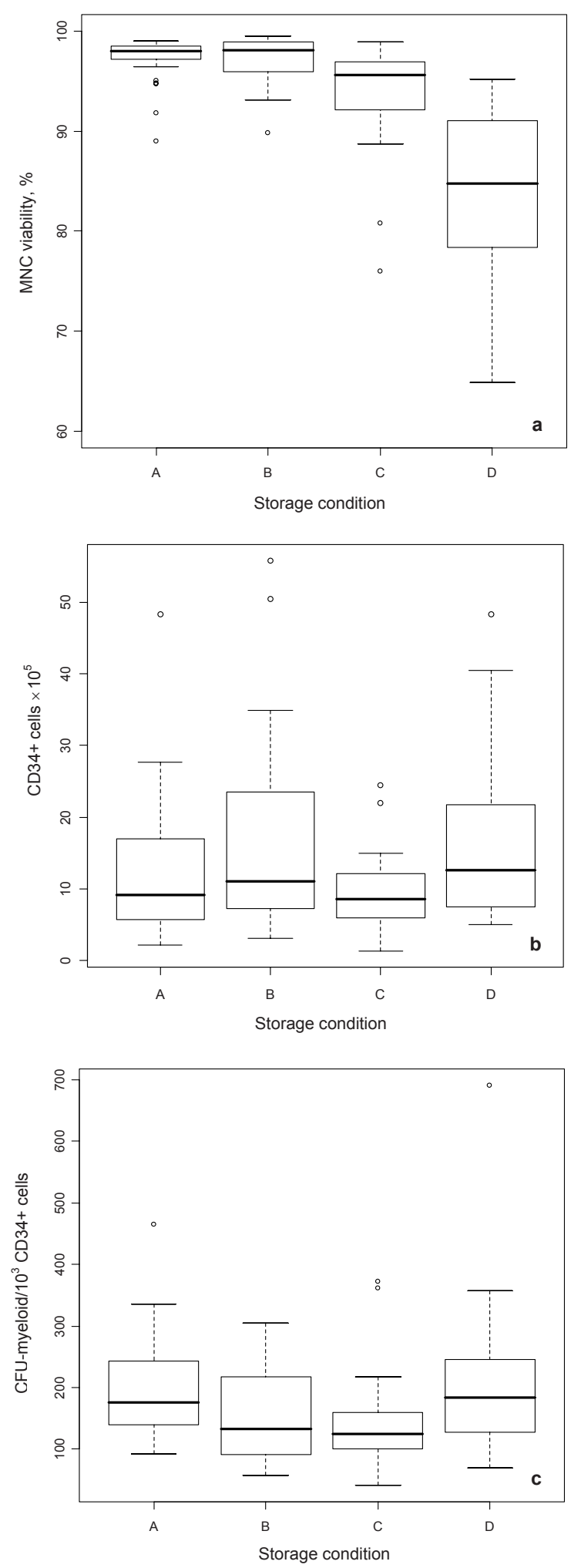

Fig. 4. a Influence of temperature and storage time on leukocyte viability in $\mathrm{MNC}$, $\mathbf{b}$ content of viable CD34/CD45+ cells in CB donations, c $\mathrm{CFU}$-myeloid $/ 10^{3} \mathrm{CD} 34 / \mathrm{CD} 45+$ cells. Before analysis, $\mathrm{CB}$ donations had been stored either (A) $0-24 \mathrm{~h}$ at room temperature $(\mathrm{n}=31)$; (B) $0-24 \mathrm{~h}$ at $8{ }^{\circ} \mathrm{C}(\mathrm{n}=22)$; (C) $25-48 \mathrm{~h}$ at $8^{\circ} \mathrm{C}(\mathrm{n}=19)$, or $(\mathrm{D}) 49-80 \mathrm{~h}$ at $8{ }^{\circ} \mathrm{C}$ $(\mathrm{n}=10)$. There was a significant decline in viability with increasing storage time: group $B$ versus $C p=0.002$, group $B$ versus $D p<0.0001$; group $\mathrm{C}$ versus $\mathrm{D} p=0.0018$. Amongst others the box plots provide the 1st, 2nd (median) and 3rd quartile of the data.
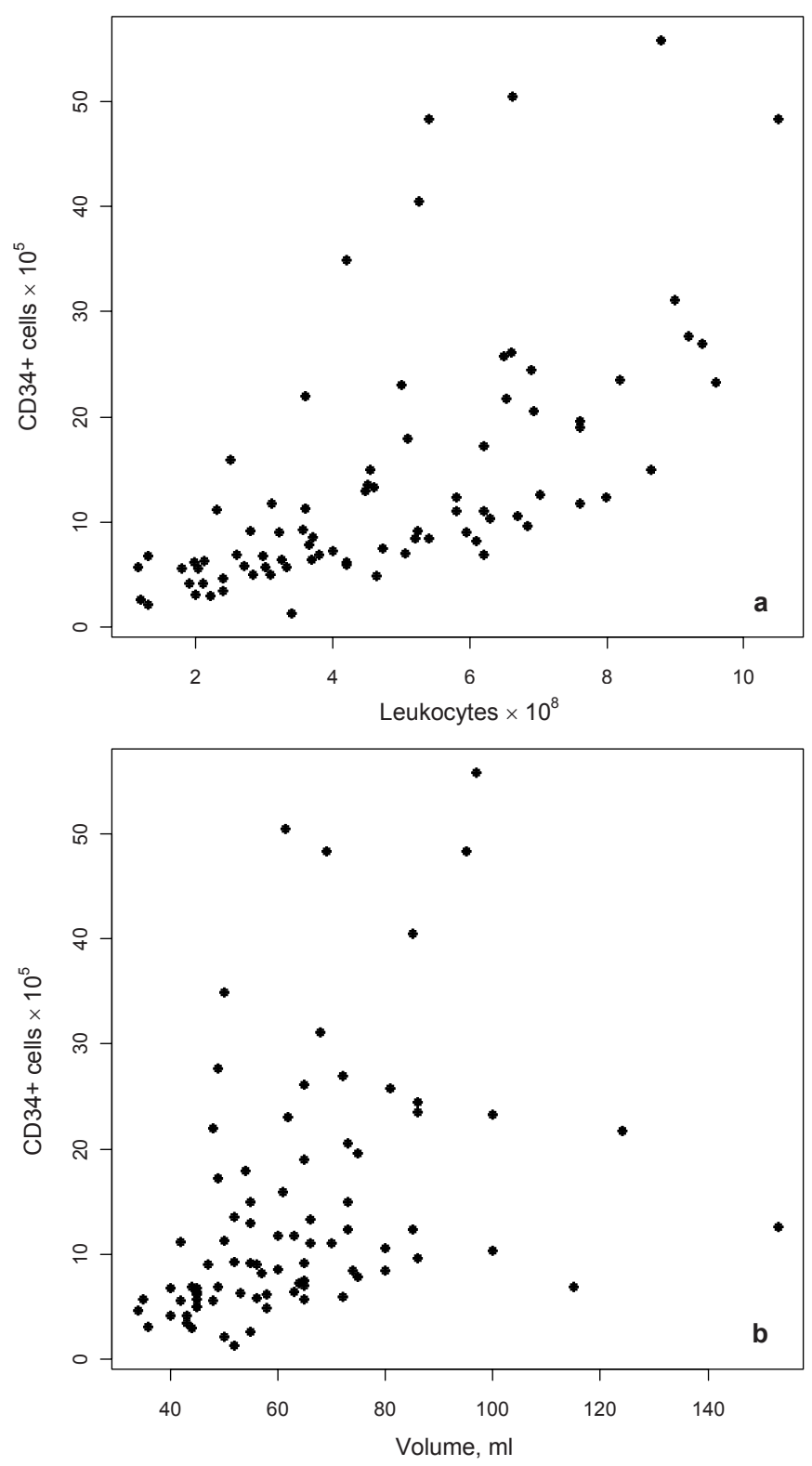

Fig. 5. Correlation of the total number of CD34/CD45+ cells $\left(\times 10^{5}\right)$ per CB donation with a the leukocyte content $\left(\times 10^{8}\right)$ per donation and b with the collected volume (ml).

CD45+ cell content (fig. 4b) and in parallel scores for CFU activity (fig. 4c) showed no significant difference throughout the tested storage periods (groups B, C, and D).

\section{Relevance of CB Volume and Leukocyte Content}

There were remarkable variations between individual CB donations with respect to volume, cell numbers, and particularly CD34/CD45+ cell content. An important question in terms of quality control is whether the $\mathrm{CB}$ volume and the leukocyte count would correlate with hematopoietic progenitor content, determined by the percentage of CD34/CD45+ cells. The amount of CD34/CD45+ cells per donation positively correlated with the leukocyte content in an exponential manner 

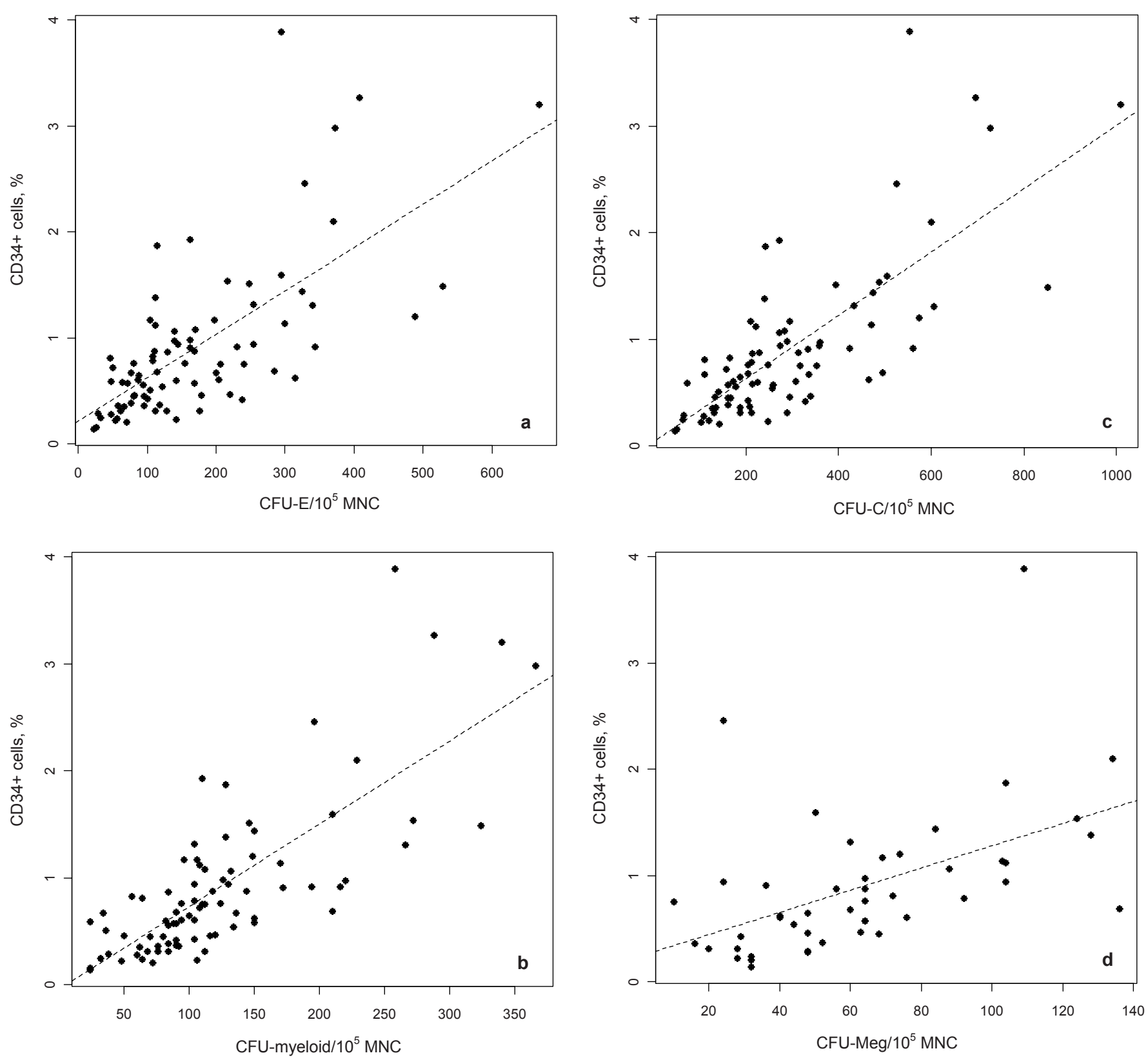

Fig. 6. Correlation between the frequency of $\mathrm{CD} 34 / \mathrm{CD} 45+$ cells in isolated $\mathrm{MNC}$ and the colony scores of different cell types per $10^{5} \mathrm{MNC}$. a CFU-E, $\mathrm{r}=0.69 ; \mathbf{b}$ CFU-myeloid, $\mathrm{r}=0.77 ; \mathbf{c}$ CFU-C, $\mathrm{r}=0.75 ; \mathbf{d}$ CFU-Meg; $\mathrm{r}=0.5$ (a, b, and $\mathrm{c}: \mathrm{n}=82, \mathrm{~d}: \mathrm{n}=47$ ).

(fig. 5a). For $\mathrm{CB}$ volume a clear positive association with the progenitor content was only evident in the range of $40-90 \mathrm{ml}$ (fig. 5b).

\section{Evaluation of Different Colony Types}

The ability of hematopoietic progenitor cells to form colonies of different blood cell types was analyzed in a functional assay in relation to the content of CD34/CD45+ cells. We saw significant correlations between the CD34/CD45+ cell content and the number of CFU-E (fig. 6a; $\mathrm{r}=0.69, \mathrm{p}<0.0001$ ), CFU-myeloid (fig. 6b; $\mathrm{r}=0.77, \mathrm{p}<0.0001$ ), and total $\mathrm{CFU}$ (fig. $6 \mathrm{c} ; \mathrm{r}=0.75$, $\mathrm{p}$ $<0.0001)$. For 47 out of 82 donations, megakaryocyte growth and differentiation was determined in collagen gels after im- munocytochemical staining of CD61 expression. After 21 days of culture, relatively low and varying counts of CFU-Meg were found (median 60, range 10-136; $n=47$ ). In some samples, only a few huge colonies were found, but in others, higher numbers of small-sized colonies were detected. This might explain the observed weak correlation between CFU-Meg numbers and CD34/CD45+ cells (fig. 6d; $r=0.50, p=0.0003$ ).

\section{Discussion}

The objective of our study was to explore the influence of various pre-processing conditions on composition and qual- 
ity of $\mathrm{CB}$ donations collected during routine deliveries in an obstetrical unit.

Our intention was to acquire comprehensive data, including also those donations outside of the limits defined by the national guidelines because this might reveal critical conditions and parameters. We evaluated the unprocessed donations and do not account for additional steps of handling as this possibly could add to or modify the variability of the samples. Even though the final products for medical application of CB stem cells are postthaw preparations, values for the basic cellular characteristics are fundamental for the assessment of quality parameters.

NRBC in CB are normally found in variable amounts. Mean values of $9.3 \pm 10 \%$ [17] are reported for uncomplicated deliveries. This is in line with our data (median $7.3 \%$, range $0.63-17.3 \%)$. Because of these strong variations between individual donations, we determined whether NRBC affected the applied assays and CB parameters. There was no interference with the of CD45+ leukocyte and CD34/CD45+ progenitor cell determination. Moreover, our data revealed that NRBC concentrations had no influence on colony scores.

Due to high variations in the collected $\mathrm{CB}$ volume, there was also a broad range of citrate concentrations, and by including donations with unusually low blood content, we were able to study conditions with citrate concentrations up to $114 \mathrm{mmol} / \mathrm{l}$. The citrate concentration had no adverse effect on leukocyte viability or clonogenic potential.

Analysis of CB donations for a relationship between progenitor cells and gestational age showed significant differences only for the CFU activity / $10^{3}$ CD34/CD45+ cells, which was lower in the group of higher gestational age (group III: 40th week +4 days to 42 nd week) compared to mid-term deliveries of group II (39th week to 40th week +3 days). Published data, which mainly refer to CD34/CD45+ content, are inconsistent: higher amounts of CD34/CD45+ cells were reported either for pre-term (35th to 37 th week) deliveries [18] or for deliveries $>39$ weeks [19], while another comprehensive study that compared donations below and above 40 weeks found no differences in CD34/CD45+ cell content [20].

Using the viable leukocyte count determined as CD45+/7AAD- cells by flow cytometry in whole $\mathrm{CB}$ and MNC preparations obviously provides a reliable basis to determine the percentage of CD34/CD45+ cells. We used this assay as single platform assay as introduced by Chin-Yee et al. [10] and stipulated by European Pharmacopeia [11]. A good positive correlation was seen between the CFU activity and the percentage of viable CD34/CD45+ cells, which was best for CFU-myeloid. CFU-E scores consisting predominantly of burst-forming units showed a somewhat less strong but positive correlation to the percentage of viable CD34/CD45+ cells.

Several storage conditions before processing were analyzed to determine their influence on $\mathrm{CB}$ quality. The German national guidelines [13] stipulate a maximal transport and storage time of $48 \mathrm{~h}$ at room temperature. The influence of storage periods over $48 \mathrm{~h}$ was tested to obtain information regarding whether this time point would be critical, with unacceptable losses in progenitor viability and content. No significant differences were found between samples stored either at room temperatures or at $8{ }^{\circ} \mathrm{C}$ during the first $24 \mathrm{~h}$. Remarkable heterogeneity with respect to progenitor content, viability, and CFU activity was seen within all groups. A gradual loss of leukocyte viability was observed after storage for 25-48 h and particularly after 49-80 h. However, CD34/CD45+ cell content was not significantly lower compared to short-term storage, and no negative impact of storage time was evident in CFU assays, suggesting that the functionality of the CB progenitor cells, i.e. grafting, was not affected by storage within the limits in this study. Therefore, according to our data, the maximal delay of $48 \mathrm{~h}$ before processing as stipulated by the German guidelines provides a safe and feasible limit.

Published data are inconsistent and show either storage at ambient temperature for $24 \mathrm{~h}$ [21] or storage at $4{ }^{\circ} \mathrm{C}$ being superior [22]. On the contrary and consistent with our data, other publications reported no differences between refrigerated storage and storage at room temperature [23, 24]. The causes for the apparent discrepancies are not evident but may be due to vague definition of temperatures and conditions on one hand and to different cell analytical methods and the heterogeneity of $\mathrm{CB}$ itself on the other hand. The importance of the particular experimental design becomes evident in the report by Moldenhauer et al. [25] who found that isolation of CD34/CD45+ cells yielded the highest clonogenicity and migration and less apoptosis if $\mathrm{CB}$ was stored for $48 \mathrm{~h}$ at room temperature prior to processing.

The national guideline [13] defines the following criteria for the specification of $\mathrm{CB}$ donations collected for transplantation: $\mathrm{CB}$ volume of $\geq 60 \mathrm{ml}$ and total nucleated cell content of $\geq 5 \times 10^{8}$ nucleated cells. So far, no limits exist for the content of CD34/CD45+ cells, viability, and NRBC content; these values only need to be declared.

The significance of parameters for CB quality control depends on whether they are predictors of the stem cell potential. Enumeration of the content of CD34/CD45+ cells in CB in conjunction with viability proved to be specific for and predictive of CFU activity [26]. The applicability of CD34/CD45+ dose for hematological recovery has been reported by Jansen et al. [27] for autologous peripheral blood progenitor cell transplantation, and therefore the selection of $\mathrm{CB}$ donations for transplantation according to CD34/CD45+ cell content appears to be a reliable parameter for progenitor activity as has been suggested by Solves et al. [28].

According to our data and to data from the literature, $\mathrm{CB}$ volume, leukocyte count, and leukocyte viability correlate only to a minor degree with the possible progenitor content. Determination of viable CD34/CD45+ counts proved to be positively related to colony-forming capacity, which therefore provides a valuable tool for quality assessment. These findings may be of relevance for adjusting the requirements in the national guidelines. 


\section{Acknowledgements}

We gratefully acknowledge the support of Dr. E. Krapfl and co-workers (Department of Gynecology, Asklepios-Klinik Langen, Germany) in the collection of CB and Dr. T. Montag, Paul-Ehrlich-Institut, Langen, for sterility testing.

Supported by the German Ministry of Health; Grant: «Erarbeitung von Qualitätsstandards für Stammzellpräparate aus Nabelschnurblut».

\section{Disclosure}

The authors declared no conflict of interest.

\section{References}

1 Kogler G, Sensken S, Airey JA, Trapp T, Muschen M, Feldhahn N, Liedtke S, Sorg RV, Fischer J, Rosenbaum C, Greschat S, Knipper A, Bender J, Degistirici O, Gao J, Caplan AI, Colletti EJ, Almeida-Porada G, Muller HW, Zanjani E, Wernet P: A new human somatic stem cell from placental cord blood with intrinsic pluripotent differentiation potential. J Exp Med 2004;200:123-135.

2 Michel G, Rocha V, Chevret S, Arcese W, Chan KW, Filipovich A, Takahashi TA, Vowels M, Ortega J, Bordigoni P, Shaw PJ, Yaniv I, Machado A, Pimentel P, Fagioli F, Verdeguer A, Jouet JP, Diez B, Ferreira E, Pasquini R, Rosenthal J, Sievers E, Messina C, Iori AP, Garnier F, Ionescu I, Locatell F, Gluckman E; Eurocord Group: Unrelated cord blood transplantation for childhood acute myeloid leukemia: a Eurocord Group analysis. Blood 2003; 102:4290-4297.

3 Chao NJ, Koh LP, Long GD, Gasparetto C, Horwitz M, Morris A, Lassiter M, Sullivan KM, Rizzieri DA: Adult recipients of umbilical cord blood transplants after nonmyeloablative preparative regimens. Biol Blood Marrow Transplant 2004;10:569-575.

4 Peterson DA: Umbilical cord blood cells and brain stroke injury: bringing in fresh blood to address an old problem. J Clin Invest 2004;114:312-314.

$>5$ Kohn DB, Weinberg KI, Nolta JA, Heiss LN, Lenarsky C, Crooks GM, Hanley ME, Annett G, Brooks JS, el-Khoureiy A, et al: Engraftment of gene-modified umbilical cord blood cells in neonates with adenosine deaminase deficiency. Nat Med 1995; 1:1017-1023.

6 van Burik JA, Brunstein CG: Infectious complications following unrelated cord blood transplantation. Vox Sang 2007;92:289-296.

7 Cairo MS, Wagner EL, Fraser J, Cohen G, van de Ven C, Carter SL, Kernan NA, Kurtzberg J: Characterization of banked umbilical cord blood hematopoietic progenitor cells and lymphocyte subsets and correlation with ethnicity, birth weight, sex, and type of delivery: a Cord Blood Transplantation (COBLT) Study report. Transfusion 2005;45:856866.

$>8$ Schwinger W, Benesch M, Lackner H, Kerbl R, Walcher M, Urban C: Comparison of different methods for separation and ex vivo expansion of cord blood progenitor cells. Ann Hematol 1999;78:364-370.
-9 McCullough J, McKenna D, Kadidlo D, Schierman $\mathrm{T}$, Wagner J: Issues in the quality of umbilical cord blood stem cells for transplantation. Transfusion 2005;45:832-841.

10 Chin-Yee I, Anderson L, Keeney M, Sutherland DR: Quality assurance of stem cell enumeration by flow cytometry. Canadian QASE Study Group. Cytometry 1997;30:296-303.

11 European Pharmacopoeia: Numeration of CD34/ CD45+ cells in haematopoietic products; 2008, 01/2008:20723.

12 Miharada K, Hiroyama T, Sudo K, Nagasawa T, Nakamura Y: Efficient enucleation of erythroblasts differentiated in vitro from hematopoietic stem and progenitor cells. Nat Biotechnol 2006;24:12551256.

13 Bundesärztekammer und Paul-Ehrlich-Institut: Richtlinien zur Transplantation von Stammzellen aus Nabelschnurblut $(\mathrm{CB}=$ CordBlood). Dtsch Ärztebl 1999;96:A-1297-A-1304.

14 Lin LI: A concordance correlation coefficient to evaluate reproducibility. Biometrics 1989;45:255268.

15 Holm S: A simple sequentially rejective multiple test procedure. Scand J Statistics 1979;6:65-70.

16 Meyer TP, Hofmann B, Zaisserer J, Jacobs VR, Fuchs B, Rapp S, Weinauer F, Burkhart J: Analysis and cryopreservation of hematopoietic stem and progenitor cells from umbilical cord blood. Cytotherapy 2006;8:265-276.

17 McCarthy JM, Capullari T, Thompson Z, Zhu Y, Spellacy WN: Umbilical cord nucleated red blood cell counts: normal values and the effect of labor. J Perinatol 2006;26:89-92.

18 Solves P, Larrea L, Soler MA, Mirabet V: Relationship between gestational age and cord blood quality. Transfusion 2001;41:302-304.

19 Mancinelli F, Tamburini A, Spagnoli A, Malerba C, Suppo G, Lasorella R, de Fabritiis P, Calugi A: Optimizing umbilical cord blood collection: impact of obstetric factors versus quality of cord blood units. Transplant Proc 2006;38:1174-1176.
20 Askari S, Miller J, Chrysler G, McCullough J: Impact of donor- and collection-related variables on product quality in ex utero cord blood banking. Transfusion 2005;45:189-194.

21 Campos L, Roubi N, Guyotat D: Definition of optimal conditions for collection and cryopreservation of umbilical cord hematopoietic cells. Cryobiology 1995;32:511-515.

22 Tsagias N, Kouzi-Koliakos K, Karagiannis V, Alamdari DH, Koliakos G: Time and temperature before processing influence the recovery of umbilical cord blood hematopoietic progenitors. Transfusion 2007;47:1550-1552.

23 Bertolini F, Gibelli N, Lanza A, Cuomo A, delia Cuna GR, Nelson EJ: Effects of storage temperature and time on cord blood progenitor cells. Transfusion 1998;38:615-617.

24 Koenigbauer UF, Burger SR, McCullough J: Nonfrozen preservation of umbilical cord blood. Transfusion 2002;42:1383-1384.

25 Moldenhauer A, Wolf J, Habermann G, Genter G, Kiesewetter H, Salama A: Optimum storage conditions for cord blood-derived hematopoietic progenitor cells prior to isolation. Bone Marrow Transplant 2007;40:837-842.

26 Van Haute I, Lootens N, De Smet S, De Buck C, Verdegem L, Vanheusden K, Pinxteren J, Vandekerckhove B: Viable CD34+ stem cell content of a cord blood graft: which measurement performed before transplantation is most representative? Transfusion 2004;44:547-554.

27 Jansen EM, Hanks SG, Terry C, Akard LP, Thompson JM, Dugan MJ, Jansen J: Prediction of engraftment after autologous peripheral blood progenitor cell transplantation: CD34, colony-forming unit-granulocyte-macrophage, or both? Transfusion 2007;47:817-823.

28 Solves P, Carbonell-Uberos F, Mirabet V, Roig R: CD34+ cell content for selecting umbilical cord blood units for cryopreservation. Transfusion 2007; 47:552-553. 